\title{
ICT Utilization in Supply Chain Environmental Collaboration Practices as the Moderator of Firms' Financial Performance
}

\author{
Łukasz Małys (D)
}

check for updates

Citation: Małys, Ł. ICT Utilization in Supply Chain Environmental Collaboration Practices as the

Moderator of Firms' Financial

Performance. Sustainability 2022, 14, 958. https://doi.org/10.3390/ su14020958

Academic Editor: Ewa Ziemba

Received: 14 December 2021

Accepted: 13 January 2022

Published: 15 January 2022

Publisher's Note: MDPI stays neutral with regard to jurisdictional claims in published maps and institutional affiliations.

Copyright: (C) 2022 by the author. Licensee MDPI, Basel, Switzerland. This article is an open access article distributed under the terms and conditions of the Creative Commons Attribution (CC BY) license (https:// creativecommons.org/licenses/by/ $4.0 /)$.
Institute of International Business and Economics, Poznań University of Economics and Business, 61-875 Poznań, Poland; lukasz.malys@ue.poznan.pl

\begin{abstract}
The purpose of this study is to verify whether increasing the intensity of ICT utilization in environmental collaboration practices (ECPs) in the supply chain has a positive impact on firms financial performance (FP). As such, it answers the call for investigating the moderators of firms' FP in their environmental supply chain management. The paper presents the results of a study conducted among 500 firms located in Poland with the use of the CATI technique. The research results show that increasing the intensity of ICT utilization in ECPs, in most cases, does not affect the firms' FP. Statistically significant relations were observed only in green design ECPs, which shows that increasing the intensity of ICT utilization in green design ECPs reduces the likelihood of revenue growth thanks to ECPs implementation. The paper fills a research gap in the moderating role of the intensity of ICT utilization in increasing financial benefits thanks to the implementation of ECPs in the supply chain. As such, it contributes to the environmental supply chain management literature. The results highlight the need for further research on the moderators of firms' financial benefits from ECPs implementation, which should be studies in isolation but also jointly, to verify their combined effect. Also, the character of different ECPs categories should be studied to link them with the most appropriate ICT.
\end{abstract}

Keywords: keyword environmental supply chain management; environmental collaboration practices; ICT; green supply chain

\section{Introduction}

Currently, firms are under pressure to revise their operations in line with sustainable development principles [1,2]. One of these is the reduction of the environmental impact of business activity [3]. Initial environmental-related concepts in business were limited to compliance with governmental regulations [4]. Later, environmental issues became part of firms' internal strategies and were regarded as a means of improving competitive advantage [5]. Since the beginning of the 21st century, the major focus is on supply chain collaboration in achieving environmental standards [6].

The issue of environmental collaboration in the supply chain has led to the formulation of the concept of environmental supply chain management (ESCM) (a nomenclature table presenting all the abbreviations used and their meaning is included in the Nomenclature). Srivastava [7] defined this as "integrating environmental thinking into the supply chain management, including product design, material sourcing and selection, manufacturing processes, delivery of the final product to the consumers as well as end-of-life management of the product after its useful life" (in his paper Srivastava was referring to green supply chain practices (GSCP); both terms-green and environmental-are commonly used in the literature and referred to the same concepts; for the clarity of the presentation, no matter the original terminology, the term "environmental" will be used in this paper, except for direct citations.) As will be explained later, the paper contributes to the ESCM literature by researching specifics, included in it issues. Various aspects of ESCM have been studied; some examples include drivers and barriers of its introduction in firms [8], 
structuring the supply chain in line with ESCM principles [9,10], or sustainable (including environmental) performance measures [11]. It is also frequently discussed under the topic of ESCM practices [12-14]. Golicic and Smith [1], generally defined these practices "as activities or actions taken to reduce or eliminate the environmental impact of supply chain management-related functions or processes" [1].

Vachon [15] proposed to divide ESCM practices into environmental collaboration (ECPs) and environmental monitoring (EMPs). According to Vachon, "environmental collaboration can be defined as the planning and development of environmental activities and projects that require direct involvement of an organization whether with its suppliers or with its customers to jointly develop environmental solutions" [15]. Collaboration within the supply chain in implementing ECPs should increase, compared to the "traditional" supply chain, and requires the active participation of partners [16].

On the other hand, "environmental monitoring implies environmental activities in the supply chain that have market-based or arm's-length transaction characteristics. It usually involves activities like an examination of a supplier's environmental practices through publicly disclosed environmental records, questionnaires, and audits conducted by either the buyer or an independent third party" [15]. Practices in this group influence relationships in the supply chain, for example by providing criteria for supplier selection, but are designed and executed internally with no or little collaboration. As such, they are not analyzed in this paper.

The research on the motivators of firms' engagement in ESCM practices (including ECPs) reveal that, among others, they intend to achieve an increase in financial performance (FP) with such activities-cost reduction is directly mentioned in the studies, and the potential influence on revenues indirectly (by customer pressure to offer environmentally friendly products, or increased reputation of the firm) $[8,17,18]$. However, some research on ESCM practices' actual impact on firms' FP offer mixed (positive, negative, and nonsignificant) results [1,19-23]. As Yunus and Michalisin [12] state "such testing is still in the developmental stages". Because of that, the need for investigating the moderators of ESCM and firms' FP is raised in the literature $[16,24,25]$. The utilization of ICT is suggested to be one of these moderators [26]. As will be presented later in the paper, the influence of ICT on various aspects of ESCM (including non-financial performance) has been analyzed in the literature. However, papers researching the moderating effect of ICT utilization in ECPs on firms' FP are missing, creating a research gap.

As explained later in the paper, ECPs is a broad category, which includes a number of subcategories, ranging from green design to reverse logistics, e.g., [13,27]. Each of these subcategories include several specific practices, which may require different ICTs being applied, and offer different possibilities for improving the FP. It is worth investigating the potential moderating effect on firms' FP of ICT utilization in all these subcategories separately, as well as altogether jointly (entire ECPs category), as presented in Figure 1. This is in line with Thöni and Tjoa's suggestion, that "IT may improve different elements of the supply flow" [26].

ICT utilization in ESCM and its effect on firms' performance was studied in different ways. Researchers analyzed the integration of ICT in ESCM, and its updating [28], the general roles of ICT in ESCM [29], or the utilization of specific ICT solutions in specific practices, e.g., planning for reduced carbon emissions [30]. The possibility of using different ICT solutions for different environmental practices creates potential for measuring the intensity of ICT utilization in ECPs and its moderating effect on firms' FP. The intensity of ICT utilization in ECPs may be calculated as a proportion of the ECPs supported by ICT, which is similar to the approach to other ICT-related studies [31]. 


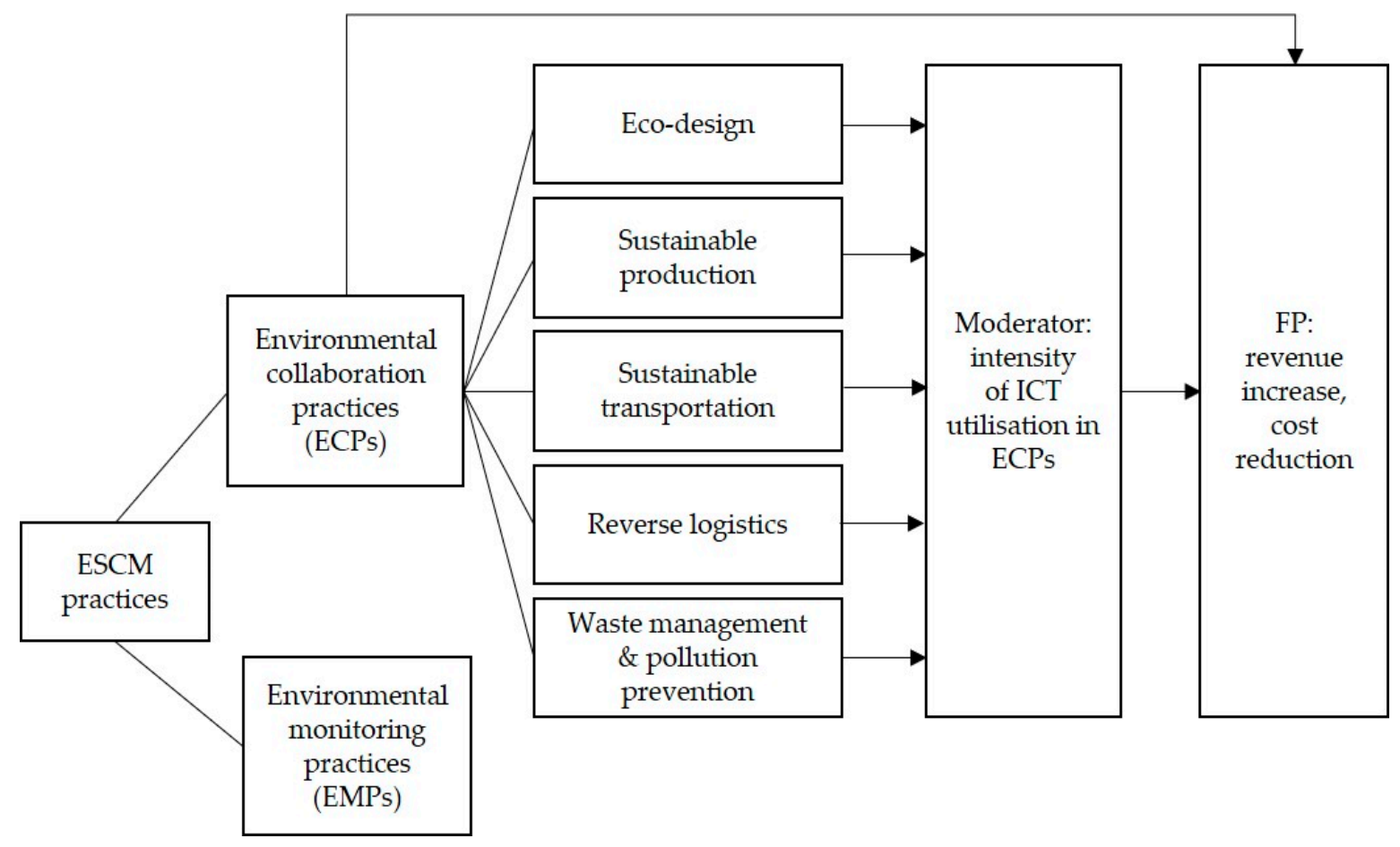

Figure 1. Conceptual framework.

Taking the above considerations into account, the research question is: Does the intensity of ICT utilization in ECPs affect FP of companies? As it is assumed that the impact may be positive, the aim of the paper is to verify whether increasing the intensity of ICT utilization in ECPs has a positive impact on firms' FP. FP is measured in the study by two indicators, separately: increase in revenues and cost reduction achieved because of the implementation of ECPs. The paper will verify whether the firms achieving these benefits differ in the intensity of their ICT utilization in ECPs from firms not achieving these financial results. Figure 1 presents the conceptual framework of the paper; however, the empirical research covered only the last part, i.e., the moderating effect of the intensity of ICT utilization in ECPs on FP.

The paper presents the results of the study conducted among 500 firms located in Poland with the use of the CATI (Computer-Assisted Telephone Interview) technique and a standardized survey questionnaire. The Mann-Whitney $U$ test was conducted to verify whether increasing the intensity of the ICT utilization in ECPs increases the probability of (1) an increase in revenues, (2) a decrease in costs due to the firms' involvement in such practices.

The paper contributes to the ESCM literature by verifying the moderating effect of the intensity of ICT utilization in ECPs in improving their FP thanks to the implemented ECPs. As such, it answers the call for investigating the moderators of ESCM and firms performance. The paper also has managerial implications, as it examines the potential benefits from supporting ECPs by the utilization of ICT.

The paper is structured as follows. First, in section two, issues related to the influence of ICT in the ESCM on firms' performance are discussed. In particular, rare studies investigating the impact on FP are presented. Also, examples presenting the role of ICT in the ESCM in generating non-financial performance are discussed, as such studies dominate in the literature. Second, in section three, ECPs identified in the literature are presented. This part includes the division of ECPs into various categories identified in the literature. Later, in section four, the research methodology is explained, followed by the presentation of the research results in section five. The last section of the paper presents conclusions, discusses the results, and indicates directions for further research. 


\section{ICT Utilization in ECPs and Firms' Performance}

As stated earlier, several studies have focused on investigating the impact of ESCM practices (including ECPs) on firms' performance. The identified impact specifically on FP varied, and was identified as positive, negative, or nonsignificant in different studies [1,19-23]. Such results suggest the need for identifying the moderators, which increase the likelihood of improving firms' FP thanks to the implementation of ESCM practices $[16,24,25]$. ICT is believed to be one of such moderators, which may help in implementing ESCM practices effectively, allowing for an increase in performance [26].

Some prior studies were focused particularly on ICT utilization in ESCM (including ECPs) and its influence on various measures of a firm's performance [32-34]. However, to my best knowledge, there are almost no empirical studies verifying how ICT utilization in ECPs may influence firms' FP. One exception includes the empirical paper of MendozaFong et al. [28], who have conducted such research in the Mexican maquiladora export industry. They reported a positive and statistically significant impact of the integration of ICT on the benefits from the green supply chain; however, the effect of the integration was small. In their analysis, they used an index of nine different financial and non-financial benefits from the green supply chain management, which included, among others, cost reduction, increased sales, and increased income. In the analysis, authors did not divide the ESCM practices into separate categories, leaving space for further studies.

Moreover, Kurnia et al. [29] have explored the roles that the information system and information technology (IS/IT) play in supporting sustainable supply chain management practices. They have analyzed, conceptually based on the literature review, the impact of IS/IT on the three dimensions of sustainable development (economic, environmental, and social) separately. The focus of the paper was on describing the potential roles (in the paper referred to as "automate, informate, transform, and infrastructure") that ICT in ESCM can play in generating various performance indicators, rather than empirical verification. Some of the conclusions presented in the paper are particularly important. They underline that the "adequate and appropriate applications of IS/IT are essential to help businesses implement SSCM practices" [29] (p. 12). They also state that "the changes highlighted by a shift to a SSCM focus now implies that relevant activities in the IS/IT domain and the broader responsibility (and specific roles) of IS/IT management require further changes as a result" [29] (p. 3). Thus, they highlight the need for modifications in the ICT domain to meet the need of the ESCM.

A relatively large number of papers address the issue of ITC's utilization impact on firms' sustainability-related, non-economic performance, i.e., their environmental or social performance. A large amount of research addresses the issue of ICT utilization in the calculation of the environmental and social impact, especially carbon emission [30,32], fuel consumption, and fatality reduction [33,35], or the shortening of vehicle routes [36,37]. The literature also indicates the use of ICT in planning the location of facilities, e.g., warehouses [38], which affects the sustainability performance of the entire supply chain. The positive impact of ICT on the implementation of reverse logistics practices is reported [34]. ICT can also improve the information exchange between firms related to the product life cycle assessment [39]. In fact, information exchange increase facilitated by ICT is one of the major benefits reported in sustainability literature [29,40]. It seems that some of these benefits achieved by the utilization of ICT may directly influence firms' FP, though this impact was not researched.

\section{Environmental Collaboration Practices in the Supply Chain}

When studying sustainability-related business practices, some terminological confusion is observed. First, different terms are applied to name the same or similar phenomenasome examples include sustainable business practices, e.g., [41], sustainable development initiatives, e.g., [42], sustainable supply chain practices, e.g., [27,43,44], sustainable supply chain management practices, e.g., [45], green supply chain practices, e.g., [15], or environmental supply chain management (ESCM) practices [8]. These differences are partly guided 
by the spectrum of the analyzed practices, which may be focused on environmental aspects only, or also include social issues. It also may be limited to practices assuming cooperation in the supply chain or include firms' internal initiatives.

Second, different classifications of the practices exist in the literature. The existing classifications seem to be subject to the influence of the industries analyzed in the different research, or propose broad, strategy-oriented categories.

An example of the latter include studies investigating general sustainable business practices, without a focus on supply chains, which refer to Hart's natural resource-based view of firms [12]. Hart [46] introduced three interconnected strategies-pollution prevention, product stewardship, and sustainable development—under which specific sustainable business practices may be identified. They include, for example, emission and waste reduction, product life cycle analysis, the development of low-impact technologies, the consideration of the social impacts of a firm's operations, and the engagement of various groups of stakeholders [47]. The division of specific practices is based on the increasing strategic commitment to sustainability.

Another classification was proposed by Golicic and Smith [1], who conducted a meta-analysis based on 31 studies to determine the impact of environmental supply chain practices on firms' market-based, operational-based, and accounting-based forms of firms' performance. They specified four groups of the practices: upstream supplier facing (e.g., supplier partnership, purchasing policies), design (e.g., eco-design, product innovation), production (e.g., pollution prevention, lean manufacturing), and downstream customer facing (e.g., logistics process, customer cooperation) [1]. This classification makes an attempt to reflect the supply chain links, with the supplier and customer relations exposed.

Some other examples include classifications designed for specific industries. Gopal and Thakkar [27], in their research on the impact of sustainable supply chain practices on firms' performance in the Indian automotive industry, distinguished five types of practices: lean practices, eco design practices, continuous improvement, risk management, and customer cooperation. They link these general practices with specific activities. Lean practices are related to minimizing waste and emission, as well as efficiently using materials and natural resources. Design practices relate to effective supply and technical innovation. Continuous improvement is understood as "a key performance indicator of sustainability in the automobile industry in areas including energy consumption, materials and production, air emissions, and treating of end-of-life vehicles that are associated with preassembly, assembly, and usage stages of the life cycle of the car", and "customer cooperation", which means cooperation with the customer for eco design, and green packaging using less energy during product transportation [27]. The authors do not provide a definition of risk management as a sustainable supply chain practice.

In a similar study on green supply chain practices in the automotive industry, Diabat et al. [13] introduced main practices and sub-practices. The main practices included internal environmental management, green purchasing, customer environmental collaboration, investment recovery, reverse logistics, design for the environment, and supplier environmental collaboration, with a number of specific sub-practices.

Both studies above were conducted in the automotive industry [13,27] and include a mixture of different categories of sustainability-related practices, including strategic adjustments inside the firm facilitating environmental collaboration, as well as actual collaborative activities.

In an already mentioned study, Vachon [15] proposed to divide green supply chain practices into those involving environmental collaboration (ECPs) and environmental monitoring (EMPs). The division is similar to Seuring and Müller's [16] two groups of sustainable supply chain strategies: supply chain management for sustainable products, and supplier evaluation for risk and performance. Both proposals divided sustainable practices into the ones which require actual collaboration, and the ones which are the prerequisite of cooperation. Environmental collaboration includes practices which can be undertaken in cooperation with the supply chain partners. However, they can be 
further divided into more specific subcategories, based, for example, on the criterion of the operational character of the practices.

Apart from the classifications, the literature also gives examples of a number of specific practices which can be undertaken in collaboration with supply chain partners. Green design ECPs include, among others, the reduction of raw materials and other resources necessary for production (including energy), reduction of the use of environmentally unfriendly or harmful raw materials, reduction of packaging (in transport and sales), product durability increase, and the possibility of its repair or waste minimization $[3,7,13]$. A number of ECPs included in this category require cooperation between various, independent entities. Working with suppliers can determine the types of raw materials and other resources used. Often, key suppliers are also involved in the product development process, especially if they provide finished components. The importance of purchasers (both intermediaries and end users) is especially visible in accepting the proposed solutions and the possibility of reducing packaging or changing it to more environmentally friendly forms. ICT primarily provides infrastructure helpful in managing this type of practice and improves the flow of information between the entities involved, often geographically distant [29].

Sustainable operations include practices related to production, transportation, reverse logistics, and waste management and pollution prevention. Many ECPs included in these categories are described in the literature [26]. These practices include the calculation of carbon emissions, e.g., [30] and related changes in the area of warehousing and transport [48], the impact of IT on the localization of important nodes, e.g., production centers [49] or warehouse centers [38] aimed at the implementation of the sustainable development principles, or the increase in work and transportation safety [50]. At the same time, it is indicated that cooperation within these ECP categories may concern a relatively large number of entities, including competitors (e.g., joint transport reducing the harmful environmental impact) [26]. Reverse logistics involves the flow of information, raw materials, means of production, and finished goods from the place of consumption to the place of their origin for the purpose of their proper disposal or recovery of their value [7]. Practices in this category are often described as " $3 R$ ": reuse, recycle, return [11].

\section{Research Methodology}

To achieve the aim of the paper, quantitative research was conducted in September 2020 with the use of the CATI (Computer-Assisted Telephone Interview) technique and a standardized survey questionnaire. The respondents were drawn from the "Pl total database" covering 1,113,035 (as of September 2020) companies located in Poland. The research intention was to get responses from 500 companies. To reach this target, 2011 companies had to be contacted, i.e., a $24.9 \%$ response rate was achieved. As intended, a total of 500 randomly selected firms located in Poland participated in the study and answered the survey questions. The pool included firms of various industries and sizes; however, the number of microenterprises in the pool was deliberately limited to $20 \%$ due to their lower expected involvement in ECPs. Companies from 26 different industries participated in the study, including industries with relatively large environmental impacts (e.g., mining, food), and relatively small environmental impacts (e.g., professional and consulting services). The respondents were representatives of the top management of the firms.

The survey included two questions to each firm about their financial performance. Each firm was asked whether, as a result of involvement in ECPs, the firm recorded (1) an increase in revenues, and (2) a decrease in costs. This allowed for the identification of groups of firms indicating or not indicating the achievement of specific financial benefits.

As part of the literature research, a range of ECPs have been identified. Two criteria were made when selecting the practices in the literature studies: they should include environmental aspects, and they should allow for joint implementation with supply chain partners. The practices were also classified in more specific ECP categories: 9 in green design, 10 in sustainable production, 5 in sustainable transportation, 1 in reverse logistics, 
and 3 in waste management and pollution prevention (see Figure 1). This classification was inspired by the literature studies presented earlier, but followed a different logic, according to which the categories should reflect a firm's operation, rather than their strategic approach or supply chain links. It was assumed that similar ICTs may be rather used in similar operational, then strategic, areas (e.g., the same ICT in transportation, no matter if it's applied to upstream or downstream collaboration in the supply chain). Under each of these categories, specific ECPs may be identified. The full list of specific ECPs included in the research is presented in the Table 1.

Table 1. Environmental collaboration practices in supply chain.

\begin{tabular}{|c|c|}
\hline Green Design Practices & Source \\
\hline 1. Use of environmentally friendly packaging. & {$[12,13,27]$} \\
\hline $\begin{array}{l}\text { 2. Developing products that contain less harmful, hazardous, and } \\
\text { toxic substances compared to the prototype. }\end{array}$ & {$[12,13,20,27]$} \\
\hline 3. Product development that enables their easy recycling. & {$[12,20]$} \\
\hline $\begin{array}{l}\text { 4. Product development that considers the reduction of } \\
\text { packaging. }\end{array}$ & [12] \\
\hline $\begin{array}{l}\text { 5. The development of products that allow the re-use of their } \\
\text { components or materials used. }\end{array}$ & {$[7,12,13,20]$} \\
\hline $\begin{array}{l}\text { 6. Developing products that enable their easy and relatively } \\
\text { environmentally friendly withdrawal from use. }\end{array}$ & {$[7,12,13]$} \\
\hline 7. Development of products that are easy to repair or regenerate. & {$[7,12,13]$} \\
\hline $\begin{array}{l}\text { 8. Development of products allowing for their longer use } \\
\text { compared to the prototype. }\end{array}$ & [12] \\
\hline $\begin{array}{l}\text { 9. Developing products that require less raw materials, } \\
\text { production materials, energy, etc., to be produced compared to } \\
\text { the prototype. }\end{array}$ & {$[7,12,13,15,16,20,27,51]$} \\
\hline \multicolumn{2}{|l|}{ Sustainable Production Practices } \\
\hline $\begin{array}{l}\text { 1. Use of renewable sources of supply (including energy, raw } \\
\text { materials, and recycled materials). }\end{array}$ & {$[11,12]$} \\
\hline 2. Recycling in the workplace. & {$[7,12,13,20]$} \\
\hline 3. Measuring the environmental impact of production. & {$[12,15]$} \\
\hline $\begin{array}{l}\text { 4. Location of production and warehouse centers based on } \\
\text { environmental analyses. }\end{array}$ & {$[7,11,12,16,49]$} \\
\hline 5. Disassembly of end-of-use products. & {$[12,13,20]$} \\
\hline 6. Reuse of components of end-of-life products. & {$[12,13,20,52]$} \\
\hline 7. Reduction of resource losses during production. & {$[1,27,46,52]$} \\
\hline 8. Provisions of product repair and restoration services. & {$[12,13,52]$} \\
\hline $\begin{array}{l}\text { 9. Reduction of the use of hazardous, harmful, toxic substances in } \\
\text { production. }\end{array}$ & {$[11,15,27]$} \\
\hline $\begin{array}{l}\text { 10. Reduction of the use of raw materials, production materials, } \\
\text { energy, etc., in production. }\end{array}$ & {$[11,12,27,52]$} \\
\hline \multicolumn{2}{|l|}{ Sustainable Transportation Practices } \\
\hline 1. Organization of transport with other entities. & {$[12,13]$} \\
\hline 2. Shortening of transport routes. & {$[12,48]$} \\
\hline 3. Reduction of exhaust emissions in transport. & {$[11,13,27,30]$} \\
\hline 4. Transport design based on environmental analyses. & {$[11,12]$} \\
\hline 5. Measuring the environmental impact of transport. & {$[11,12]$} \\
\hline \multicolumn{2}{|l|}{ Reverse Logistics Practice } \\
\hline $\begin{array}{l}\text { 1. Recycling of manufactured products or their } \\
\text { components-collection and processing. }\end{array}$ & {$[7,11,13,27,52]$} \\
\hline \multicolumn{2}{|l|}{ Waste Management and Pollution Prevention Practices } \\
\hline 1. Preventing the emission of pollutants. & {$[1,15,46,47,52]$} \\
\hline 2. Waste reduction. & {$[1,7,12,27,46,52]$} \\
\hline 3. Reduction of pollutant emissions. & {$[7,11,15,46,52]$} \\
\hline
\end{tabular}


Respondents were asked to indicate whether their firms are involved in individual ECPs, and if so, whether this cooperation is supported by the utilization of ICT. To determine the intensity of the utilization of ICT in ECPs, the percentage of ECPs supported by the use of ICT was measured for each firm. A similar approach was applied in other ICT-related studies to measure the intensity of the ICT utilization [31]. Another possible approach to measure the intensity of ICT utilization could be to analyze the absolute number of ECPs supported by ICT, e.g., [53]. However, here the comparison of the absolute number of ECPs supported by ICT utilization was abandoned, because for different firms the number of possible ECPs to be implemented may be different by definition (some firms, due to the nature of their activity, may not be able to take some ECPs at all, e.g., service firms cannot be involved in some green design practices).

To verify whether increasing the intensity of ICT utilization in ECPs increases the probability of (1) an increase in revenues, and (2) a decrease in costs due to firms' involvement in such practices, the Mann-Whitney $U$ test was conducted. The tests were carried out separately for both the financial indicators included in the research, without creating one index of the financial result. The reason for this approach was the assumption that some ECPs categories may have an impact on one of the analyzed financial indicators, but not on the other. Thus, there were two grouping variables in the analysis:

1. increase in revenues thanks to the implemented ECPs-allowing to distinguish groups of firms that have recorded such an increase, and firms that have not recorded such an increase,

2. decrease in costs thanks to the implemented ECPs-allowing to distinguish groups of firms that have recorded such a decrease, and firms that have not recorded such a decrease.

Test variables were the intensity of ICT utilization in ECPs, calculated as a percentage of the ECPs supported by the utilization of ICT. This intensity has been calculated separately for: all 28 ECPs included in the study, 9 green design ECPs, 10 sustainable production ECPs, 5 sustainable transportation ECPs, 1 reverse logistics ECP, and 3 waste management and pollution prevention ECPs. The reason for carrying out the analyses separately for different ECPs categories was the willingness to verify whether the intensity of ICT utilization in any of them has a greater or lesser impact on the FP.

\section{Research Results}

In the first stage of the analysis, the mean values and medians of the intensity of ICT utilization in ECPs were compared in the groups declaring and not declaring revenue growth thanks to the implemented ECPs (see Table 2). The higher the mean and median values in a given group, the more ECPs are supported by the use of ICT in the analyzed categories.

For all six categories, the intensity of ICT utilization is higher in the groups of firms that do not declare an increase in revenues due to their involvement in ECPs. In the case of the median, this regularity is visible in the case of four categories. In the other two, the median value is 1000 for both groups of firms-achieving and not achieving the revenue growth. This means that more than half of the respondent firms involved in the ECPs in these categories support them with the use of ICT. However, the mean values show that there are differences in the intensity of ICT utilization between firms also in these two categories. 
Table 2. Revenue growth as a result of implemented ECPs and intensity of ICT utilization: Descriptive statistics results.

\begin{tabular}{|c|c|c|c|c|c|}
\hline \multirow{2}{*}{ ECPs Categories } & \multirow{2}{*}{ Revenue Growth } & \multirow{2}{*}{$\mathbf{N}$} & \multicolumn{2}{|c|}{ Intensity of ICT Utilization in ECPs } & \multirow{2}{*}{ Significance } \\
\hline & & & Mean & Median & \\
\hline \multirow[b]{2}{*}{ All ECPs } & No & 230 & 0.6873 & 0.8209 & \multirow[b]{2}{*}{0.093} \\
\hline & Yes & 56 & 0.5937 & 0.6443 & \\
\hline \multirow{2}{*}{ Green design ECPs } & No & 197 & 0.6891 & 1.000 & \multirow[b]{2}{*}{0.015} \\
\hline & Yes & 45 & 0.5324 & 0.5714 & \\
\hline \multirow{2}{*}{ Sustainable production ECPs } & No & 201 & 0.7012 & 0.8571 & \multirow{2}{*}{0.121} \\
\hline & Yes & 48 & 0.6002 & 0.6667 & \\
\hline \multirow{2}{*}{$\begin{array}{c}\text { Sustainable transportation } \\
\text { ECPs }\end{array}$} & No & 186 & 0.6187 & 0.8000 & \multirow{2}{*}{0.311} \\
\hline & Yes & 42 & 0.5444 & 0.6667 & \\
\hline \multirow{2}{*}{ Reverse logistics ECPs } & No & 86 & 0.6628 & 1.000 & \multirow{2}{*}{0.639} \\
\hline & Yes & 15 & 0.6000 & 1.000 & \\
\hline \multirow{2}{*}{$\begin{array}{l}\text { Waste management and } \\
\text { pollution prevention ECPs }\end{array}$} & No & 128 & 0.7409 & 1.000 & \multirow{2}{*}{0.636} \\
\hline & Yes & 29 & 0.7126 & 1.000 & \\
\hline
\end{tabular}

$\mathrm{N}$ : number of firms in the group.

The next stage of the analysis was to verify whether the identified differences are statistically significant. For this purpose, the Mann-Whitney U test was carried out separately for each of the ECPs' category. According to the methodology, a null hypothesis in the Mann-Whitney $U$ test indicates no differences between the groups distinguished by the grouping variables. The null hypothesis in the Mann-Whitney $U$ test is accepted if the $p>0.05$. In other words, in such a case, the identified differences in the intensity of ICT utilization in ECPs are statistically insignificant due to exceeding the critical level of $p=0.05$. As shown by the data presented in the last column of Table 2, in the case of five out of six of the ECP categories, the differences in the mean values and medians are statistically insignificant. This means that increasing the intensity of ICT utilization in ECPs does not affect the revenue.

The discussed differences are statistically significant in the green design ECPs category $(p=0.015)$. Table 3 presents the detailed results of the Mann-Whitney U test.

Table 3. Mann-Whitney U test results: Revenue growth and the green design ECPs category.

\begin{tabular}{|c|c|c|c|c|}
\hline \multicolumn{5}{|c|}{ Ranks } \\
\hline & $\begin{array}{l}\text { Revenue Growth as a } \\
\text { Result of Implemented } \\
\text { Practices }\end{array}$ & $\mathbf{N}$ & Mean Rank & $\begin{array}{l}\text { Sum of } \\
\text { Ranks }\end{array}$ \\
\hline \multirow{3}{*}{$\begin{array}{l}\text { ICT support for the } \\
\text { green design practices }\end{array}$} & No & 197 & 126.40 & $24,901.00$ \\
\hline & Yes & 45 & 100.04 & 4502.00 \\
\hline & Total & 242 & & \\
\hline \multicolumn{5}{|c|}{ Test statistics $^{\text {a }}$} \\
\hline \multicolumn{5}{|c|}{$\begin{array}{l}\text { ICT support for the green } \\
\text { design practices }\end{array}$} \\
\hline Mann-Whitney U & 3467.000 & & & \\
\hline Wilcoxon W & 4502.000 & & & \\
\hline $\mathrm{Z}$ & -2.423 & & & \\
\hline Asymp. Sig. (2-tailed) & 0.015 & & & \\
\hline
\end{tabular}

Effect size $\mathrm{r}$ can be calculated for the obtained results:

$$
\mathrm{r}=\frac{|\mathrm{Z}|}{\sqrt{\mathrm{N}}}=\frac{|-2.423|}{\sqrt{242}}=0.1558
$$


The effect size $r=0.1558$ is considered small [54,55].

As shown by the data presented in Tables 2 and 3, the intensity of ICT utilization in green design ECPs is higher in the group of firms that do not declare revenue growth (68.91\% of ECPs supported by the utilization of ICT, Mdn = 1.000) compared to firms that declare an increase in revenue (53.24\% of ECPs supported by the utilization of ICT, Mdn $=0.5714$ ) thanks to the implemented ECPs. The Mann-Whitney U test indicates that this difference is statistically significant, $\mathrm{U}\left(\mathrm{N}_{\mathrm{no}}=230, \mathrm{~N}_{\mathrm{yes}}=39\right)=3467.000, \mathrm{Z}=-2.423$, $p=0.015$.

In this case, it means that increasing the intensity of ICT utilization in green design ECPs reduces the likelihood of revenue growth thanks to the implementation of ECPs. This effect is considered small $(\mathrm{r}=0.1558)$.

Table 4 presents the mean values and medians of the intensity of ICT utilization in ECPs in the groups declaring and not declaring a decrease in costs thanks to the implemented ECPs. The higher the mean and median values in a given group, the more ECPs are supported by the use of ICT. In most cases, these values are higher for groups declaring a decrease in costs due to the implemented ECPs. This could indicate that, with the increasing intensity of ICT utilization in ECPs, there is a greater chance of a firm's costs falling. The opposite is true in the case of practices classified as reverse logistics, and waste management and pollution prevention.

Table 4. Cost decrease as a result of implemented ECPs and intensity of ICT utilization: Descriptive statistics results.

\begin{tabular}{|c|c|c|c|c|c|}
\hline \multirow[t]{2}{*}{ ECPs Categories } & \multirow{2}{*}{$\begin{array}{l}\text { Revenue } \\
\text { Growth }\end{array}$} & \multirow{2}{*}{$\mathbf{N}$} & \multicolumn{2}{|c|}{$\begin{array}{c}\text { Intensity of ICT } \\
\text { Utilization in ECPs }\end{array}$} & \multirow{2}{*}{ Significance } \\
\hline & & & Mean & Median & \\
\hline \multirow{2}{*}{ All ECPs } & No & 200 & 0.6533 & 0.7500 & \multirow{2}{*}{0.163} \\
\hline & Yes & 86 & 0.7055 & 0.8750 & \\
\hline \multirow{2}{*}{ Green design ECPs } & No & 170 & 0.6555 & 0.8000 & \multirow{2}{*}{0.544} \\
\hline & Yes & 72 & 0.6703 & 1.000 & \\
\hline \multirow{2}{*}{$\begin{array}{c}\text { Sustainable production } \\
\text { ECPs }\end{array}$} & No & 174 & 0.6750 & 0.7500 & \multirow{2}{*}{0.327} \\
\hline & Yes & 75 & 0.6975 & 1.000 & \\
\hline \multirow{2}{*}{$\begin{array}{c}\text { Sustainable transportation } \\
\text { ECPs }\end{array}$} & No & 165 & 0.5939 & 0.7500 & \multirow{2}{*}{0.431} \\
\hline & Yes & 67 & 0.6341 & 1.000 & \\
\hline \multirow{2}{*}{ Reverse logistics ECPs } & No & 78 & 0.6538 & 1.000 & \multirow{2}{*}{0.988} \\
\hline & Yes & 23 & 0.6522 & 1.000 & \\
\hline \multirow{2}{*}{$\begin{array}{c}\text { Waste management \& } \\
\text { pollution prevention ECPs }\end{array}$} & No & 116 & 0.7557 & 1.000 & \multirow{2}{*}{0.399} \\
\hline & Yes & 41 & 0.6789 & 1.000 & \\
\hline
\end{tabular}

However, as shown by the data presented in the last column of Table 4, all the differences observed are statistically insignificant. This implies accepting null hypotheses for all the analyzed ECP categories. Therefore, the conducted analysis shows that increasing the intensity of ICT utilization does not affect the probability of cost reduction due to the implementation of ECPs.

\section{Discussion}

The intensity of ICT utilization in ECPs was analyzed in the research as an isolated moderator, without considering the impact of other moderators on the possibility of improving a firm's FP. However, the literature indicates several other moderators that may contribute to the benefits of implementing ECPs. For example, Carter and Rogers [50], based on the conducted literature review and interviews with firm representatives, indicate four supporting facets of the triple bottom line that affect the generation of benefits due to involvement in ESCM practices: risk management, transparency, strategy, and the orga- 
nizational culture. These supporting facets require actual changes in firms to fully accept sustainability principles. Perhaps, such "strategic" changes should come first, before the utilization of ICT in ECPs can bring financial benefits.

Another reason for the results obtained may be the failure to adjust the ICT used to the specificity of the implemented ECPs. This supposition is, to some extent, consistent with the research of Mendoza-Fong et al. [28] who examined the impact of the integration and updating of ICT on the benefits from the green supply chain. In their research, the positive impact of the integration of ICT on the combined benefits (financial and non-financial) from the green supply chain was small, but it was considerably higher in combination with updating the ICT when the ICTs were "up-to-date and applied to green supply chains" [28]. It may suggest that only with the necessary adjustments of the utilized ICT to ECPs, does it lead to a positive impact on firms' FP.

It is also possible that the utilization of ICT in ECPs has only an indirect effect on firms' FP and that the direct effect cannot be recognized. The utilization of ICT has a direct impact on factors related to ECPs, which is reported in the literature and mentioned in the presented literature review in the paper. These factors, in some cases, may directly influence firms' possibility to increase revenues and/or decrease costs. An example of such a factor is information sharing [40], which is directly influenced by the utilization of ICT and may influence firms' FP [56].

The obtained results may also flow from the adopted methodological assumptions. In the research, the intensity of ICT utilization in ECPs was measured as a percentage of all ECPs supported by the utilization of ICT, regardless of the number of specific practices implemented in the firm. It means, for example, that if a firm has implemented only one ECP and supported the implementation with ICT, the mentioned intensity was 100\%. It is possible, however, that achieving financial benefits from the implementation of ECPs is possible only after exceeding a certain critical point of engagement associated with a relatively large number of implemented ECPs.

The context in which the research was conducted may also affect the results obtained. The research included randomly selected firms of various industries and sizes, located in Poland. First, it is possible that some specifics of the Polish market limit the possibility of improving the FP thanks to the implementation of ECPs or utilization of ICT as a moderator. Second, firms operating in some industries may be more predisposed or have greater opportunities to implement ECPs, support them with the use of ICT, and improve their FP through such practices, e.g., Gopal and Thakkar [27]. Research covering firms from a number of industries may therefore not give unequivocal results. It should be noted here that, so far, a large part of the research covering both ECPs and the utilization of ICT in ECPs were done in a specific industry setting. Third, in the case of random selection, the sample includes firms with different knowledge of sustainable development, and different levels of involvement in ESCM; in fact, the involvement of some firms in sustainable development may only be superficial [11], resulting, for example, from the regulatory requirements, which limits the benefits that can be achieved by implementing ECPs [6].

Regardless of the possible reasons for the obtained results discussed above, special attention should be paid to the identified negative impact of the increasing intensity of ICT utilization in green design practices on firms' revenue. When interpreting this impact, the nature of the practices included in the ECPs category should be considered. These practices may lead to product innovation (whereas other practices may lead to process or organizational innovations). The cooperation in this field may require more personal and less ICT-based communication if expected benefits should be achieved. This means that the utilization of ICT in ECPs may lead to an increase in firms' FP only in the case of some, and not all ECPs. 


\section{Conclusions and Directions for Further Research}

The aim of the paper is to verify whether increasing the intensity of ICT utilization in ECPs has a positive impact on firms' FP. The conducted research shows that, in most cases, the differences in the intensity of ICT utilization in ECPs between firms declaring and not declaring that they did achieve certain financial benefits (increase in revenues or decrease in costs) due to the implementation of the ECPs are not statistically significant. Thus, increasing the intensity of ICT utilization in ECPs, in most cases, does not affect the firm's FP. Only in the case of the green design ECPs and their impact on the increase of revenues, were the obtained results statistically significant. The conducted analysis shows that increasing the intensity of ICT utilization in green design ECPs reduces the likelihood of revenue growth thanks to the implementation of ECPs. This effect is considered small.

As suggested by the discussion, the results have certain research implications for ECPs generally, and specifically ICT utilization in ECPs. The results highlight the need for further research on supporting facets of effective ECP implementation, and the moderators of generating financial benefits thanks to them. Such moderators can, as in the presented paper, be studied in isolation, to investigate their individual effect. However, as the research results suggest, they should be jointly analyzed as well to verify whether a combination of different moderators is necessary for certain results to be achieved. It also seems that the moderators may be different in nature-some of them more "strategic" (e.g., organizational culture), and some others more "operational" (like the intensity of the ICT utilization). Thus, it should also be analyzed whether the type of moderators influences the potential benefits it may moderate.

The results also point to the need for further research in the field of ICT utilization in ECPs. It should be investigated whether there are some conditions under which increasing the intensity of ICT utilization in ECPs is in fact beneficial from a financial perspective. In this regard, three aspects seem particularly interesting. Firstly, an impact of ICT adjustments (in the form of updating, deliberate development etc.) to the specifics of ECPs should be studied, as it seems that some ICTs lead to the generation of better results than others. Secondly, the character of different ECPs categories should be included in the research, as some of them may be better suited to being supported by the ICT utilization. Thirdly, the moderators (e.g., information sharing) of the financial benefits achieved by the increase in ICT utilization in ECPs should be studied further.

Additionally, the impact of the indicated contextual factors also requires further research, particularly in the form of case studies. Such contextual factors may include market or industry specifics, and selected company characteristics.

Based on the conducted research and its results, only limited practical recommendations may be presented. Companies should not rely too heavily on the ICT, which may be tempting especially in current times, when implementing ECPs. ICT should be rather regarded as a supporting tool, when sustainable development concept is embedded in the companies, and communication schemes between supply chain links developed. It may be also important to develop the appropriate IT capabilities to achieve potential benefits [57]. More practical implications should result from suggested further studies.

Funding: The project was financed within the Regional Initiative for Excellence program of the Minister of Science and Higher Education of Poland, years 2019-2022, grant no. 004/RID/2018/19, financing 3,000,000 PLN.

Institutional Review Board Statement: Not applicable.

Informed Consent Statement: Not applicable.

Data Availability Statement: Not applicable.

Acknowledgments: I would like to express my gratitude to my colleague, Milena Ratajczak-Mrozek, for valuable comments and suggestions.

Conflicts of Interest: The author declares no conflict of interest. 


$\begin{array}{ll}\text { Nomenclature } \\ \text { Abbreviation } & \text { Meaning } \\ \text { ESCM } & \text { environmental supply chain management } \\ \text { ECPs } & \text { environmental collaboration practices } \\ \text { EMPs } & \text { environmental collaboration practices } \\ \text { ICT } & \text { information and communication technologies } \\ \text { FP } & \text { financial performance } \\ \text { CATI } & \text { Computer-Assisted Telephone Interview } \\ \text { GSCP } & \text { green supply chain practices }\end{array}$

\section{References}

1. Golicic, S.L.; Smith, C.D. A Meta-Analysis of Environmentally Sustainable Supply Chain Management Practices and Firm Performance. J. Supply Chain Manag. 2013, 49, 78-95. [CrossRef]

2. Hoffman, A.J.; Bazerman, M.H. Changing environmental practice: Understanding and overcoming the organizational and psychological barriers. In Organizations and the Sustainability Mosaic: New Perspectives in Research on Corporate Sustainability; Sharma, M., Husted, B., Eds.; Edward Elgar Publishing: Cheltenham, UK; Northampton, MA, USA, 2007.

3. McDowall, W.; Geng, Y.-J.; Huang, B.; Barteková, E.; Bleischwitz, R.; Türkeli, S.; Kemp, R.; Doménech, T. Circular Economy Policies in China and Europe. J. Ind. Ecol. 2017, 21, 651-661. [CrossRef]

4. Walton, S.V.; Handfield, R.B.; Melnyk, S.A. The green supply chain: Integrating suppliers into environmental management processes. Int. J. Purch. Mater. Manag. 1998, 34, 2-11. [CrossRef]

5. Porter, M.E.; Van der Linde, C.G. Competitive and Green: Ending the Stalemate. Harv. Bus. Rev. 1995, 3, $120-134$.

6. Giunipero, L.C.; Hooker, R.E.; Denslow, D. Purchasing and supply management sustainability: Drivers and barriers. J. Purch. Supply Manag. 2012, 18, 258-269. [CrossRef]

7. Srivastava, S.K. Green supply-chain management: A state-of-the-art literature review. Int. J. Manag. Rev. 2007, 9, 53-80. [CrossRef]

8. Walker, H.; Di Sisto, L.; McBain, D. Drivers and barriers to environmental supply chain management practices: Lessons from the public and private sectors. J. Purch. Supply Manag. 2008, 14, 69-85. [CrossRef]

9. Hagelaar, G.J.L.F.; Van der Vorst, J.G.A.J. Environmental supply chain management: Using life cycle assessment to structure supply chains. Int. Food Agribus. Manag. Rev. 2001, 4, 399-412. [CrossRef]

10. Ramanathan, U.; Mazzola, E.; Mohan, U.; Bruccoleri, M.; Awasthi, A.; Garza-Reyes, J.A. How selection of collaborating partners impact on the green performance of global businesses? An empirical study of green sustainability. Prod. Plan. Control 2021, 32, 1207-1222. [CrossRef]

11. Hassini, E.; Surti, C.; Searcy, C. A literature review and a case study of sustainable supply chains with a focus on metrics. Int. J. Prod. Econ. 2012, 140, 69-82. [CrossRef]

12. Yunus, E.N.; Michalisin, M.D. Sustained competitive advantage through green supply chain management practices: A naturalresource-based view approach. Int. J. Serv. Oper. Manag. 2016, 25, 135-154.

13. Diabat, A.; Khodaverdi, R.; Olfat, L. An exploration of green supply chain practices and performances in an automotive industry. Int. J. Adv. Manuf. Technol. 2013, 68, 949-961. [CrossRef]

14. Perotti, S.; Zorzini, M.; Cagno, E.; Micheli, G.J. Green supply chain practices and company performance: The case of 3PLs in Italy. Int. J. Phys. Distrib. Logist. Manag. 2012, 42, 640-672. [CrossRef]

15. Vachon, S. Green supply chain practices and the selection of environmental technologies. Int. J. Prod. Res. 2007, 45, 4357-4379. [CrossRef]

16. Seuring, S.; Müller, M. From a literature review to a conceptual framework for sustainable supply chain management. J. Clean. Prod. 2008, 16, 1699-1710. [CrossRef]

17. Haddock-Fraser, J.E.; Tourelle, M. Corporate motivations for environmental sustainable development: Exploring the role of consumers in stakeholder engagement. Bus. Strat. Environ. 2010, 19, 527-542. [CrossRef]

18. Dhull, S.; Narwal, M. Drivers and barriers in green supply chain management adaptation: A state-of-art review. Uncertain Supply Chain Manag. 2016, 4, 61-76. [CrossRef]

19. Wood, D.J. Measuring Corporate Social Performance: A Review. Int. J. Manag. Rev. 2010, 12, 50-84. [CrossRef]

20. Zhu, Q.; Sarkis, J.; Lai, K.-H. Green supply chain management: Pressures, practices and performance within the Chinese automobile industry. J. Clean. Prod. 2007, 15, 1041-1052. [CrossRef]

21. Jung, S.; Nam, C.; Yang, D.-H.; Kim, S. Does Corporate Sustainability Performance Increase Corporate Financial Performance? Focusing on the Information and Communication Technology Industry in Korea. Sustain. Dev. 2017, 26, 243-254. [CrossRef]

22. Jum'A, L.; Zimon, D.; Ikram, M. A Relationship Between Supply Chain Practices, Environmental Sustainability and Financial Performance: Evidence from Manufacturing Companies in Jordan. Sustainability 2021, 13, 2152. [CrossRef]

23. Agyabeng-Mensah, Y.; Ahenkorah, E.; Afum, E.; Agyemang, A.N.; Agnikpe, C.; Rogers, F. Examining the influence of internal green supply chain practices, green human resource management and supply chain environmental cooperation on firm performance. Supply Chain Manag. Int. J. 2020, 25, 585-599. [CrossRef]

24. Lee, S.M.; Kim, S.T.; Choi, D. Green supply chain management and organizational performance. Ind. Manag. Data Syst. 2012, 112, 1148-1180. [CrossRef] 
25. Kim, J.H.; Youn, S.; Roh, J.J. Green Supply Chain Management orientation and firm performance: Evidence from South Korea. Int. J. Serv. Oper. Manag. 2011, 8, 283. [CrossRef]

26. Thöni, A.; Tjoa, A.M. Information technology for sustainable supply chain management: A literature survey. Enterp. Inf. Syst. 2015, 11, 828-858. [CrossRef]

27. Gopal, P.; Thakkar, J. Sustainable supply chain practices: An empirical investigation on Indian automobile industry. Prod. Plan. Control 2015, 27, 49-64. [CrossRef]

28. Mendoza-Fong, J.R.; García-Alcaraz, J.L.; Jiménez Macías, E.; Ibarra Hernández, N.L.; Díaz-Reza, J.R.; Blanco Fernández, J. Role of Information and Communication Technology in Green Supply Chain Implementation and Companies' Performance. Sustainability 2018, 10, 1793. [CrossRef]

29. Kurnia, S.; Mahbubur, R.; Gloet, M. Understanding The Roles of Is/It in Sustainable Supply Chain Management. Pac. Asia Conf. Inf. Syst. Proc. 2012. Available online: https://core.ac.uk/download/pdf/301358086.pdf (accessed on 17 September 2021).

30. Sourirajan, K.; Centonze, P.; Helander, M.E.; Katircioglu, K.; Ben-Hamida, M.; Boucher, C. Carbon management in assembly manufacturing logistics. IBM J. Res. Dev. 2009, 53, 8:1-8:16. [CrossRef]

31. Forth, J.; Mason, G. Information and Communication Technology (ICT) Adoption and Utilisation, Skill Constraints and Firm Level Performance: Evidence from UK Benchmarking Surveys; Citeseer; National Institute of Economic and Social Research: London, UK, 2004.

32. Ibrahim, K.M.; Waziri, S.I. Improving ICT and renewable energy for environmental sustainability in sub-Saharan Africa. J. Res. Emerg. Mark. 2020, 2, 82-90. [CrossRef]

33. Iacob, M.E.; van Sinderen, M.J.; Steenwijk, M.; Verkroost, P. Towards a reference architecture for fuel-based carbon management systems in the logistics industry. Inf. Syst. Front. 2013, 15, 725-745. [CrossRef]

34. Daugherty, P.J.; Richey, R.; Genchev, S.E.; Chen, H. Reverse logistics: Superior performance through focused resource commitments to information technology. Transp. Res. Part E Logist. Transp. Rev. 2005, 41, 77-92. [CrossRef]

35. Van Geenhuizen, M. ICT Applications on the Road to Sustainable Urban Transport. 2011. Available online: https://www. openstarts.units.it/bitstream/10077/6059/1/vanGeenhuizen_ET41.pdf (accessed on 12 October 2021).

36. Santos, L.; Coutinho-Rodrigues, J.; Antunes, C.H. A web spatial decision support system for vehicle routing using Google Maps. Decis. Support Syst. 2011, 51, 1-9. [CrossRef]

37. Leyerer, M.; Sonneberg, M.-O.; Heumann, M.; Breitner, M.H. Shortening the Last Mile in Urban Areas: Optimizing a Smart Logistics Concept for E-Grocery Operations. Smart Cities 2020, 3, 585-603. [CrossRef]

38. Bosona, T.; Nordmark, I.; Gebresenbet, G.; Ljungberg, D. GIS-Based Analysis of Integrated Food Distribution Network in Local Food Supply Chain. Int. J. Bus. Manag. 2013, 8, 13. [CrossRef]

39. Borsato, M. Bridging the gap between product lifecycle management and sustainability in manufacturing through ontology building. Comput. Ind. 2014, 65, 258-269. [CrossRef]

40. Khan, M.; Hussain, M.; Saber, H.M. Information sharing in a sustainable supply chain. Int. J. Prod. Econ. 2016, 181, 208-214. [CrossRef]

41. Ortiz-De-Mandojana, N.; Bansal, P. The long-term benefits of organizational resilience through sustainable business practices Strateg. Manag. J. 2016, 37, 1615-1631. [CrossRef]

42. Halati, A.; He, Y. Intersection of economic and environmental goals of sustainable development initiatives. J. Clean. Prod. 2018, 189, 813-829. [CrossRef]

43. Wagner, B.; Svensson, G. Sustainable supply chain practices: Research propositions for the future. Int. J. Logist. Econ. Glob. 2010, 2, 176. [CrossRef]

44. Tay, M.Y.; Rahman, A.A.; Aziz, Y.A.; Sidek, S. A Review on Drivers and Barriers towards Sustainable Supply Chain Practices. Int. J. Soc. Sci. Humanit. 2015, 5, 892-897. [CrossRef]

45. Morali, O.; Searcy, C. A Review of Sustainable Supply Chain Management Practices in Canada. J. Bus. Ethics 2012, 117, 635-658. [CrossRef]

46. Hart, S.L. A natural-resource-based view of the firm. Acad. Manag. Rev. 1995, 20, 986-1014. [CrossRef]

47. Fowler, S.J.; Hope, C. Incorporating sustainable business practices into company strategy. Bus. Strategy Environ. 2006, 16, 26-38. [CrossRef]

48. Guenther, E.; Farkavcová, V.G. Decision making for transportation systems as a support for sustainable stewardship. Manag. Res. Rev. 2010, 33, 317-339. [CrossRef]

49. Verma, S.; Chaudhuri, R. Creating Customer Satisfaction and Profitable Value Chain with E-commerce in Rural India: A case based approach. Int. J. Bus. Insights Transform. 2008, 2, 51-63.

50. Carter, C.R.; Rogers, D.S. A framework of sustainable supply chain management: Moving toward new theory. Int. J. Phys. Distrib. Logist. Manag. 2008, 38, 360-387. [CrossRef]

51. Tura, N.; Keränen, J.; Patala, S. The darker side of sustainability: Tensions from sustainable business practices in business networks. Ind. Mark. Manag. 2018, 77, 221-231. [CrossRef]

52. Agyemang, M.; Kusi-Sarpong, S.; Khan, S.A.; Mani, V.; Rehman, S.T.; Kusi-Sarpong, H. Drivers and barriers to circular economy implementation: An explorative study in Pakistan's automobile industry. Manag. Decis. 2019, 57, 971-994. [CrossRef]

53. Mwombe, S.O.; Mugivane, F.I.; Adolwa, I.S.; Nderitu, J.H. Evaluation of Information and Communication Technology Utilization by Small Holder Banana Farmers in Gatanga District, Kenya. J. Agric. Educ. Ext. 2013, 20, 247-261. [CrossRef] 
54. Field, A. Discovering Statistics Using IBM SPSS Statistics; SAGE Publications: Los Angeles, CA, USA; Washington, DC, USA; London, UK; New Delhi, India; Singapore, 2013.

55. Pallant, J. SPSS Survival Manual: A Step by Step Guide to Data Analysis Using IBM SPSS; Routledge: London, UK, 2020.

56. Song, M.; Liao, Y. Information sharing, operations capabilities, market intelligence responsiveness and firm performance. Balt. J. Manag. 2018, 14, 58-78. [CrossRef]

57. Erkmen, T.; Günsel, A.; Altındağ, E. The Role of Innovative Climate in the Relationship between Sustainable IT Capability and Firm Performance. Sustainability 2020, 12, 4058. [CrossRef] 